\title{
SINGING THE NATURE - ETHNOBOtANICAL KNOWLEDGE IN BULGaRIAN FOLK SONGS
}

\section{CANTO CON LA NATURALEZA: CONOCIMIENTO ETNOBOTÁNICO EN CANCIONES POPULARES BÚLGARAS}

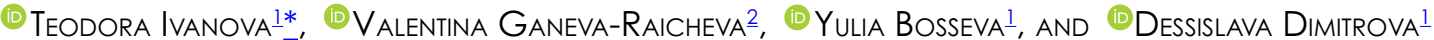

' Institute of Biodiversity and Ecosystem Research, Bulgarian Academy of Sciences, Acad. G. Bonchev St., Sofia, Bulgaria.

${ }^{2}$ Institute of Ethnology and Folklore Studies with Ethnographic Museum, Bulgarian Academy of Sciences, Acad. G. Bonchev St., Sofia, Bulgaria.

*Author for correspondence: tai@bio.bas.bg

\begin{abstract}
Background: Bulgarian poetic folklore reflects an agrarian culture deeply connected with land and nature. However, traditional ecological knowledge (TEK) transmitted through Bulgarian folklore is scarcely assessed.

Questions: What are the dimensions of the TEK related to plant diversity (native and introduced) that appear in Bulgarian folk songs and what is their potential as transmitters of TEK?

Data description: The lyrics of 10,113 Bulgarian folk songs were excerpted from major academic collections and a set of unpublished songs. Study site and dates: Current study covers songs that have been documented since mid- $19^{\text {th }}$ century onwards in the present and former Bulgarian territories and in areas that have been inhabited by ethnic Bulgarians abroad.

Methods: Common plant names and descriptions of plants and landscapes were used to detect botanical affiliations of the denoted plants. We focused on frequencies of plant representations and their functions associated with cultural, agricultural and food-processing practices.

Results: A total of 146 plant taxa from 109 genera were mentioned in $47.3 \%$ of the studied songs. Over $60 \%$ of the most frequently mentioned taxa were archaeophytes while neophytes were represented by seven taxa, denoting everyday and spiritual importance of nature.

Conclusions: Bulgarian folk songs presented wide range of nature-related information typically reported for ethnic groups outside Europe. Quantification of TEK preserved in documented poetic folklore and further assessment of performance of nature-rich folklore would allow development additional tools for evaluation of cultural significance of species, landscapes and ecosystems as well as for development of educational and inspirational materials.
\end{abstract}

Keywords: Balkans, ecosystem services, folklore, symbolic plants.

\section{Resumen}

Antecedentes: El folclore poético búlgaro refleja una cultura agraria profundamente conectada con la tierra y la naturaleza. Sin embargo, el conocimiento ecológico tradicional (TEK) transmitido a través del folclore búlgaro es incipiente.

Preguntas: ¿Cuáles son las dimensiones del TEK relacionadas con la diversidad de plantas (nativas e introducidas) que aparecen en las canciones populares búlgaras y cuál es su potencial como transmisores de TEK?

Descripción de datos: La letra de 10,113 canciones populares búlgaras se extrajo de las principales colecciones académicas y de una serie de canciones inéditas.

Lugar de estudio y fechas: Se estudiaron canciones documentadas desde mediados del siglo XIX en los territorios búlgaros actuales y anteriores y áreas habitadas por búlgaros en el extranjero.

Métodos: Se utilizaron nombres comunes y descripciones de plantas y paisajes para detectar afiliaciones botánicas. Nos centramos en las frecuencias y sus funciones asociadas con las prácticas culturales, agrícolas y de procesamiento de alimentos.

Resultados: 146 taxones de 109 géneros se mencionaron en $47.3 \%$ de los cantos estudiados. Más del $60 \%$ de los taxones registrados eran arqueófitos y siete taxones fueron neófitos, lo que denota la importancia cotidiana y espiritual de la naturaleza.

Conclusiones: Las canciones populares búlgaras presentaron mucha información de la naturaleza sobre los grupos étnicos fuera de Europa. El TEK del folclore documentado y la evaluación del folclore rico en naturaleza permitirá el desarrollo de herramientas para evaluar la importancia cultural de las especies, los paisajes y los ecosistemas, así como para el desarrollo de materiales educativos inspiradores.

Palabras clave: Balcanes, servicios ecosistémicos, folclore, plantas simbólicas.

This is an open access article distributed under the terms of the Creative Commons Attribution License CCBY-NC (4.0) international. https://creativecommons.org/licenses/by-nc/4.0/ 
Culture plays an essential role for shaping and explaining human-nature interrelations, hence it is a reservoir of traditional ecological knowledge (TEK) that has been transferred over the generations. Preserved folklore heritage was found to contribute to the current insights in nature conservation and education (Mac Coitir 2016, Pandey \& Pandey 2016, Dudareva \& Goeva 2017, Schirpke et al. 2018). Additionally, the representation of folk traditions is a popular trend that appeals to broader public and attracts interest to folklore festivals and events in Europe and beyond (Ganeva-Raycheva 2013, Wilks \& Quinn 2016, Chen \& Tao 2017, Lange 2018). Still, the continous devaluation, arrested diachronic (from adults to youngsters) and synchronic (among same age performers) transmission have hindered the natural transfer of traditional knowledge in industrialized contexts (Quave et al. 2012, Hernández-Morcillo et al. 2014, Shukla et al. 2017). In the more-and-more urbanizing societies worldwide the traditional ways of handing down of knowledge is rather questionable. On the other hand, the access to knowledge that is foreign to certain community, availability of scientific-based data and modern opportunities of sharing information allow further development and even co-creation of nature-related knowledge based on traditions (Leonti 2011, Hernándes-Morcillo et al. 2014, Díaz et al. 2018). New dynamic realities demand diverse approaches to educational and awareness interventions that could contribute to sustainability learning (Kim et al. 2017, Burton \& Riley 2018, Ramet et al. 2018, Benyei et al. 2020). Thus, sourcing of reliable, scientifically sound data for the development of such tools would rely, probably inevitably, on the alredy documented TEK and modern transmission options like social media and live streaming.

Over the recent years, the reassessment of historical data sources has revealed preserved pockets of TEK that provide valuable information for its persistence, erosion and transformation (Nedelcheva et al. 2011, Svanberg et al. 2011, Dénes et al. 2012, Kalle \& Sõukand 2012, Svanberg \& Łuczaj 2014, Kujawska et al. 2017). However, medicinal plants and healing practices have remained the main focus and little attention has given to arts, rituals and beliefs as a source of ethnobotanical knowledge (Thiselton-Dyer 1889, Watts 2007, Łuczaj 2009, 2012, Mekbib 2009, Nedelcheva \& Dogan 2011, Benítez et al. 2018, Tolstaia 2018, Ahmed et al. 2019). Historical ethnobotany explores mostly written sources but very few of these include preserved cultural heritage (Silva et al. 2014, Herrero \& Cardaño 2015).
Bulgarian musical heritage has attracted considerable attention throughout the years and for many people around the world it is the first gateway to Bulgarian culture. The transformations in function and performance and even the political contextualization of Bulgarian folk songs after the World War II were thoroughly researched (Kaufman 2001, Kaufman \& Peycheva 2004, Peycheva 2015, Rice 2017). However, the TEK preserved in various forms of the Bulgarian folklore remains unexplored from biological perspective. Older ethnographic studies (Iliev 1892, 1893, 1919, Stranski 1929) discussed briefly the symbolism and, partially, the semantic role of several plant species mentioned in the Bulgarian folklore, but did not discuss their representation in the different folklore forms. Ginchev (1890) recorded over 125 plants and plant products used in folk medicine making reference to some folk songs as a proof of the authenticity of the collected knowledge. Later ethnobotanists working in Bulgaria focused predominantly on TEK on medicinal and wild edible plants but mainly through field studies (Stranski 1929, Kitanov 1953, Stoyanov \& Kitanov 1960, Petkov 1986, Ivancheva \& Stantcheva 2000, Nedelcheva \& Dogan 2011, Nedelcheva 2013). Recent reports showed shrinkage of TEK on a global scale and Bulgaria is not an exception (Nedelcheva \& Dogan 2011, Georgiev 2013, Aswani et al. 2018).

Several ethnographic compendium works described the strong organic link of Bulgarians with nature that is reflected in folk songs, legends, fairy tales, riddles, sayings (Georgiev 1976, Vakarelski 1977, Georgieva 1993, Georgiev 2013). Nevertheless, current assessments and mapping of (cultural) ecosystem services in the country have provided contraversing evidences about the overall scores for cultural heritage (from very high for the Black Sea Coast to lowest for the Central Balkan Mts., both popular recreational sites and included in Natura 2000 network) that were attributed also to the "missing perception and understanding of the importance of ecosystems as a whole" (Vladimirov \& Petrova 2017, Nedkov et al. 2018, Gocheva et al. 2019).

The objective of the current study was to explore the diversity of wild and cultivated plants that appear in Bulgarian folk songs and to reveal the link between their biological characteristics and the role they play in the traditional songs. The study focuses on an important, yet unconsidered facet of folk songs - the poetic representation of native and non-native plant diversity and the potential of folk songs as carriers of TEK in the broader context of folklore as a systemic culture. 


\section{Materials and methods}

Bulgaria is located in the centre of the Balkan Peninsula, in South-East Europe, on an area of $110,879 \mathrm{~km}^{2}$. The country is in the transitional zone between temperate and Mediterranean climatic zones. Bulgaria is topologically diverse with altitudes ranging from sea level to nearly $3,000 \mathrm{~m}$. Bulgarian vascular flora comprises 3,840 species of Spermatophytes and 60 fern species, affiliated to 886 genera and 153 families (Biserkov et al. 2015). About $51.2 \%$ of the territory is being cultivated, $42.67 \%$ is covered with forests, and $4.9 \%$ are urban areas (Adams \& Lükewille 2010).

Present study covers folk songs documented in the current Bulgarian territory and in areas of present-day Greece, Romania, Turkey, North Macedonia, Moldova, and Ukraine inhabited by ethnic Bulgarians. Lyrics were excerpted in electronic searchable format (MS Access database) from major academic collections published from the mid-19th century onwards: Arnaudov et al. (1961-1963 - Balgarsko narodno tvorchestvo in 12 volumes), Kaloyanov (1986), Kaloyanov (1992), Mollov (2006-2017). The Sakar region (South-East Bulgaria, bordering with Turkey) was under-represented in the publications mentioned above, thus we used also a set of unpublished songs, gathered in the 1980s in Sakar Mt. and stored in the archive of the Institute of Ethnology and Folklore Studies at the Ethnographic Museum at the Bulgarian Academy of Sciences. A total of 10,113 lyrics were searched in order to identify mentions of common plant names in different Bulgarian dialects. Common plant names and descriptions of plants and landscapes were used to detect and discern, when possible, the botanical affiliations of the denoted plants. We used glossaries and botanical lists of Bulgarian plant common names from the late $19^{\text {th }}$ and early $20^{\text {th }}$ centuries (Kozarov 1925, Urumov 1926, Gerov 1895-1904, Ahtarov et al. 1939). We have taken into account only the mentioning of the species, regardless of form or derivative. Mentions of plant-related parts, products or items with no reference to species were not considered. Plant denominations were related at least to the genus rank, and, when common name and/or details mentioned in the lyrics allowed it, to the species rank and even to certain crop varieties and landraces. The Plant List (2013) was used as taxonomic references for currently accepted scientific names. Euro+MedPlantBase (2011) was used as reference for origin and distribution of the taxa found in the lyrics. The data on habitat/landscape depictions and/or ecosystem services were evaluated through their direct and sec- ondary descriptions and by the mentioning of characteristic species. Information about agricultural/horticultural practices and food production was recorded, if present.

Functional-semantic analysis of plant diversity in songs related to rituals and everyday life was performed in order to understand the place of plants in the system of folklore knowledge. The roles of plants and their utilitarian and/or cultural functions were asserted in the context of the ritual or other cultural practices described in the songs.

\section{Results}

Plant-denoting references were recorded in nearly half of the surveyed song lyrics $(47.3 \%, 4,788)$. Often more than one plant was mentioned within a single song and in a quarter of the researched songs $(1,200)$ more than three plant taxa were present. A total of 146 plant taxa from 109 genera, and 55 families were identified (Figures 1, 2 $\underline{\text { Ap- }}$ pendix 1).

Native flora was presented with 93 taxa, followed by 40 archaeophytes and 7 neophytes. The majority of the mentioned plants were wild ( 83 taxa), 53 were cultivated (crops and/or garden) plants and 11 were either wild or cultivated native ornamental and fruit-bearing plants (i.e., peony, iris, strawberry, cherry plums, etc.). At family level Rosaceae was most frequently mentioned with 1,093 citations of 16 taxa (Figure 1, Table 1). Members of Rosaceae were found nearly 1.5 and 4-times more frequently than those of Poaceae and Vitaceae families. The high incidence of references to Poaceae (757) was mainly attributable to Triticum sp. (263), the major food crop in the region, followed by Secale cereale (199), Oryza sativa (105), Panicum miliaceum (86), Hordeum vulgare (55), Avena sativa (28) and Zea mays (16). Grape vines (279 mentions) were mentioned both in narratives involving agricultural and forest habitats.

Only 15 common names remained unresolved (NOID) due to the absence of clues to the plant features or habitat characteristics in the song lyrics. For instance, ruzha, which is known as a reference to a variety of large red or yellow ornamental flowers like roses, popies, Mexican marigolds. The Tagetes species (T. recta and T. patula) are known under a variety of collective names in Bulgarian - funda, turta, kamshitsa, kadiyka, karshikapka, zhalta ruzha (yellow ruzha), however, only kamshitsa and ruzha were found mentioned in the songs.

Plants in the folk songs were described sparingly, focusing more on the interrelation between humans and nature, cultural and social aspects of human life than on 


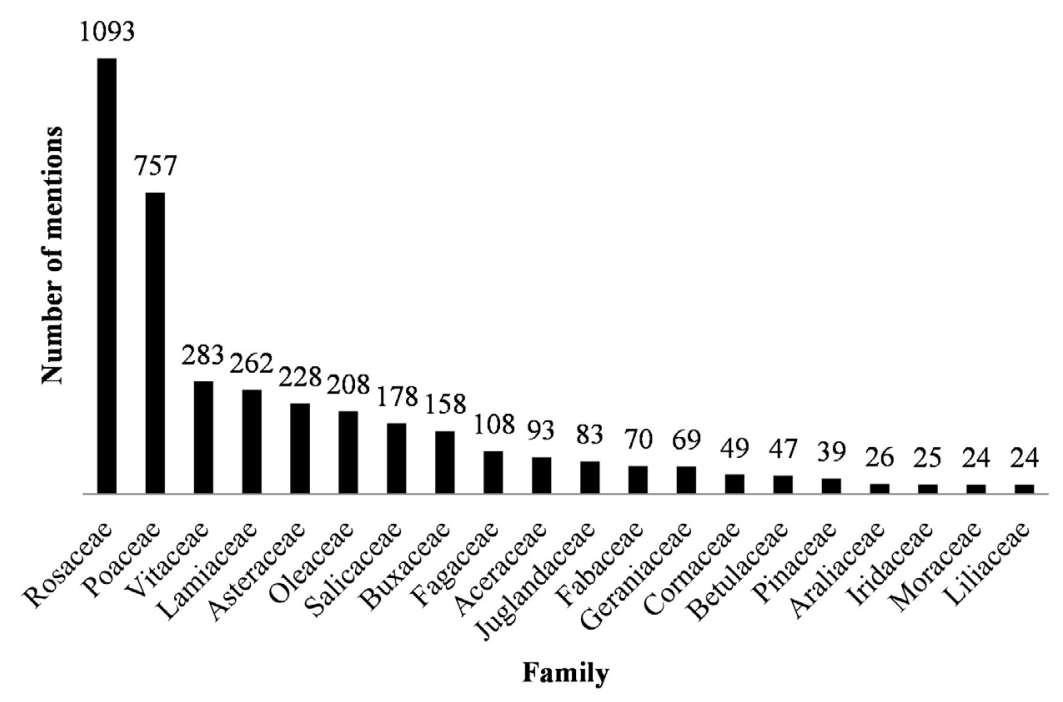

Figure 1. The 20 plant families with the highest incidence of taxa references in Bulgarian folk songs.

intentional addressing the biology and/or morphology of certain species. Most of the plant-related mentions conveyed a symbolic meaning (e.g., cosmic order, heterogeneity of landscape, Arbor mundi - posessing features both of evergreen conifer and orchard tree), but they also cast a set of images (e.g., a beautiful maiden - Abies alba, Рориlus sp., a handsome lad - Pinus sp., Acer sp.) or featured depictions of different aspects of rural livelihood (e.g., tending gardens, harvesting fields, hanging a cradle on a tree, etc.). Symbolic functions of plants were related to true-to-fact information about the species: e.g., Vitis vinifera and Hedera helix with their climbing habit were consistently found to represent relations among two persons that often overcome the distance between the worlds of the living and the dead; phenological stages of plants as a metaphor for year seasons - flowering of Chrysanthemums signifying autumn; flowering of almond and sour cherry trees signifying beginning of the spring.

The plants (trees, shrubs, vines, herbs and grasses) were elements of the narrative scenery or were personified as interlocutors or protagonists, sometimes replacing the human characters in the story. In the song lyrics with the highest number of plant references seven plants were personified as protagonists (the bride, her interlocutor, the groom, etc.) and another three complemented the scenery of the post-wedding rituals, i.e., reffering to the colour of the drinks, the flower-shaped tables and the guest placement along the table looking similar to the alternate flower arrangement along the stem:
- Заспала ли си, черешо ?*

- Не съм заспала, ягодо, чакам си либе трандафил; той е отишел на гости у кума, у босилека, у кумичката камиичка, да едът, холан, да пият. та щуо им беше софрата: синята сифа**_ софрата, а червената (сифа**)- четата; червен им божнр- виното, желтото лале- ракия.

Комар им с гайда свиреше,

Теменужката играе,

Сминчеца й са смееше:

-Теменужке ле мънинка, къко са леко подфърляш!

Теменужката говори:

"Ти си и голям и висок, доде та сльние огрее, като та сльнце препече никой та веке не бере!

"Are you already asleep, Sweet cherry?" "No, I am not asleep, Strawberry!

I'm waiting for my sweetheart - the Rose.

He went to visit

His best man, the Basil

And his wife the Marigold. 
To eat and drink together.

What was happening there?

The blue Sifa ${ }^{* *}$ was the table

The red Sifas ${ }^{* *}$ were the company.

The red Peony - their wine

The yellow Tulip - their brandy

A Mosquito was playing on a bagpipe

The Violet was dancing

The Sminchec** was jesting on her:

"Hey little Violet,

You are throwing yourself lightly!"

The Violet was answering:

"You are large and tall.

When the sun scorches you

No one wants to pluck you anymore!

* Plant names are highlighted in bold font. This folk song is from Yambol region, documented in 1911 by Bulgarian diaspora in Russian Empire (currently Ukraine). English translation - authors' free translation from Bulgarian):

** - NOID (Sifa - Convolvulus tricolor L. or Mirabilis jalapa L.; Sminchec - Xeranthemum annuum L., Antennaria dioica (L.) Gaertn. or Helichrysum arenarium (L.) Moench).

Separate plant parts (leaves, branches, fruits, flowers) were mostly used figuratively (similes and metaphors). Figurative connotations in the song lyrics pointed out a variety of plant morpho-physiological traits. For example, basil convex sepals were used to describe eyelids, pine and fir trunks - slender human body (male and female, respectively, corresponding to the grammatical gender of the Bulgarian common names). The allegorical plant depictions were detailed, demonstrating a very close observation of the natural world, for instance, giving stinging nettle to someone as an expressiom of resentment to them or shedding of apple blossom petals over a young maiden as a symbol of her stepping into adulthood. Metaphorical references to colours, i.e. olives or cherries instead of black (eyes), apples instead of red (cheeks), violet instead of blue (sky) were also widely employed. Additional examples could be found as Supplementary material ( $\underline{\mathrm{S}})$.

Irrespective of the higher taxonomic diversity of wild plants in folk songs, crops were mentioned twice more frequently ( 32 and $68 \%$, respectively). Over $60 \%$ of the most frequently mentioned taxa (over 100 mentions) were crop archaeophytes, led by apple, wheat, grape vine, rye, and sour cherry. They were referenced as food or as symbolic/ritual plants, while sweet basil and boxwood - only as ritual ones. Locally-grown crops (indigenous and ar- chaeophytes) were rendered in greater detail (concerning references to species) with a more diverse range of functionalities while foreign species were cited only as imported products. Black pepper and coffee plant were described poorly and/or falsely, e.g., black pepper was imagined as an arable crop.

Various grain crops mentioned in the folk songs illustrated very well the broad spectrum of plant-human interactions. Grains were in the foundation of rural landscape images portraying seasonality of the peasant livelihoods, wealth and prosperity as a result of bountiful harvests. They also symbolised fertility, well-being and abundance, indicating heavy work on the field and stock-breeding. For example, wheat was represented as a precious crop anticipating harvest (incl. cultivated by Christian saints or by God himself), common food and feed plant, ritual grains spilled in front of wedding processions as a charm of fertility and last but not least as a commodity traded at varying prices. This latter representation reflected the economic situation at the time when songs were created. However, a clear perception of disparity can be observed with regard to grain crops - T. aestivum, Z. mays and $O$. sativa (both as food and feed) were associated with wealth and even luxury, while Hordeum vulgare, Avena sativa and Panicum miliaceum were mentioned as crops or food indicative of poverty and low social status. Avena sativa was even further denounced by being excluded from ritual food in several mythic songs.

While grains were main descriptors of the agricultural open fields, trees and shrubs from Rosaceae family occupied more intimate close space near the home, in the garden/orchard and rarely represented noticeable places in the wild (e.g., solitary Prunus avium trees in forest habitats). Rosaceae taxa were found valued both for the nutritive qualities of their fruits and for the ritual and/or symbolic connotations of the whole plant and/or parts of it (Table 1). In the current study we found examples referring to plant ecology, morphology and biology, phenological cycles of the representatives of this family. The beauty, fecundity and elegance of Rosaceae trees, along with the alluring sweet taste and crispiness of the cultivated and wild fruits, were mentioned in a variety of utilitarian situations (as eating/snacking, orchard tending or harvesting) and/or figurative meanings (literary figures for maritalsexual symbols, courtship, etc.).

Food plants, apart from Rosaceae and Poaceae, were far less represented in the Bulgarian folk songs. Legumes and leafy vegetables were linked to mythical creatures and Biblical narratives (Cicer arietinum, Allium sp.), ritual food 
Table 1. Functions of the Rosaceae taxa in Bulgarian folk songs.

\begin{tabular}{|c|c|c|c|}
\hline Taxon & Part mentioned & Function & Number of mentions \\
\hline Crataegus monogyna Jacq. & tree, fruit & $\begin{array}{l}\text { timber, food plant, landscape } \\
\text { element }\end{array}$ & 11 \\
\hline Cydonia oblonga Mill. & tree, fruit & fruit crop, comparative (woman) & 109 \\
\hline Fragaria sp. & fruit & $\begin{array}{l}\text { food plant, comparative } \\
\text { (woman) }\end{array}$ & 3 \\
\hline Malus domestica Borkh. & tree, flower, fruit & $\begin{array}{l}\text { fruit crop, comparative (woman, } \\
\text { red-skin color) }\end{array}$ & 295 \\
\hline Malus sylvestris (L.) Mill. & tree & symbolic (Arbor mundi) & 3 \\
\hline Prunus armeniaca $\mathrm{L}$. & fruit & comparative (woman) & 1 \\
\hline Prunus avium (L.) L. & tree, flower, fruit & $\begin{array}{l}\text { fruit crop, symbolic (Arbor } \\
\text { mundi), comparative (woman, } \\
\text { dark-eye color) }\end{array}$ & 211 \\
\hline Prunus cerasus L. & tree, flower, fruit & $\begin{array}{l}\text { fruit crop, symbolic (Arbor } \\
\text { mundi), comparative (woman, } \\
\text { dark-eye color) }\end{array}$ & 155 \\
\hline Prunus domestica $\mathrm{L}$. & tree, fruit & food plant, landscape element & 3 \\
\hline Prunus dulcis (Mill.) D. A. Webb & tree, kernel & $\begin{array}{l}\text { fruit crop, comparative (eye } \\
\text { form) }\end{array}$ & 5 \\
\hline Prunus spinosa $\mathrm{L}$. & shrub & $\begin{array}{l}\text { honey-bearing plant, ritual plant, } \\
\text { magic plant, landscape element }\end{array}$ & 6 \\
\hline Pyrus communis $\mathrm{L}$. & tree, flower, fruit & $\begin{array}{l}\text { fruit crop, symbolic (Arbor } \\
\text { mundi), landscape element }\end{array}$ & 61 \\
\hline Rosa canina $\mathrm{L}$. & shrub, fruit & food plant, landscape element & 2 \\
\hline Rosa sp. & shrub, flower & ornamental, landscape element & 165 \\
\hline Rubus caesius $\mathrm{L}$. & fruit, thorny stem & $\begin{array}{l}\text { comparative (dark color, } \\
\text { woman), obstacle on a road }\end{array}$ & 19 \\
\hline Rubus idaeus L. & fruit & $\begin{array}{l}\text { food plant, comparative } \\
\text { (woman) }\end{array}$ & 39 \\
\hline
\end{tabular}

preparation (Phaseolus vulgaris, Urtica dioica, Vicia faba) and, rarely, to everyday scenarios (Lens culinaris, Rumex acetosa, Allium cepa, Allium sativum). Vegetables originating from the Americas were mentioned metaphorically, in storylines not related to food, or were mentioned as luxury goods. Capsicum annuum, Solanum lycopersicon and Solanum tuberosum were cited 9, 1 and 0 times, respectively. Interestingly, folk songs did not reflect a broad range of wild edible plants that were historically and/or currently known from Bulgaria (Nedelcheva 2013, Ivanova et al. $\underline{2018 \mathrm{a}}, \underline{b})$. Wild edible plants were represented only by two edible greens (Urtica dioica and Rumex acetosa) and few wild berries (raspberry, strawberry, dewberry).
One of the leading positions of Lamiaceae was due mostly to one species - Ocimum basilicum (256 mentions), an archaeophyte, with an unknown time frame of its introduction in the Balkans. The major traditional use of this species in Bulgaria, as an indispensable part of decorations for burial and memorial rites, does not surface in the lyrics of folk songs, most likely because such rituals were never accompanied by singing. Ocimum basilicum, portrayed in Bulgarian folk sogs, had mainly symbolic roles in ritual/religious or romantic storylines. Sweet basil was associated with and attributed to the Christian God, and the Ruler on Earth. In the folk songs the fragrance of sweet basil was considered 'the scent of the Christian 
soul' contrasted to 'the aroma of the Muslim soul', which 'smelled of boiled/dry elder' (Sambucus ebulus), presenting these plants as cultural markers. Basil was also a principal element of the kitka (nosegay), which both maidens and lads wore as a symbolic decoration. Thus, O. basilicum dominated among ornamental plants, especially in rituals and in mythical/religious scenes described in the folk songs, and that are common for other Balkan and Mediterranean countries as well (Simoons 1998, Pieroni et al. 2012). Sweet basil alone or with other ornamental species was often accompanied by descriptions of gardening practices, e.g., garden creation and tending, flower care and picking, which exhausted the concept of a home garden as rendered in Bulgarian poetic folklore. Last but not least, a specific use of sweet basil in Bulgarian folk songs was for its function as an insect repellent.

Although Lamiaceae is one of the families richest in species in Bulgaria, and many of its representatives had been well known as traditionally-used medicinal, aromatic and spice plants among Bulgarians (Ivancheva \& Stantcheva 2000), only Satureja, Thymus and Melissa were mentioned in folk songs alongside $O$. basilicum. It is worth mentioning that aromatic plants (e.g., O. basilicum, Thymus sp., Geranium macrorrhizum) were found to exhibit special verbal abilities, i.e., they appear as talkative protagonists, which implies an intrinsic perception of the plants' volatiles as a communication tool.

The members of Asteraceae family were appreciated for various reasons. The genus Artemisia occured most frequently (202 mentions). Artemisia species were present as an element of landscapes (sceneries) (i.e., ruderalization of abandoned fields and gardens), but they were also described as medicinal and magical plants. The symbolic, ritual and decorative significance of Artemisia is evidenced by its presence as a regular element of a maiden's kitka together with other plants. This was specifically valid for the songs from Northeastern Bulgaria where $A r$ temisia was frequently mentioned as remarkable for the local landscape which corresponds to the steppic vegetation typical for that part of the country. Helichrysum arenarium (zhult smil or smin) was also identified as part of the kitka for its highly valued yellow colour, which symbolises the sun. Tanacetum vulgare was mentioned rarely (10) with a reference to its magical, decorative and protective functions. It was believed to ward off evil forces and ill-meant intentions and therefore was grown near the front gate to guard the house. This practice still persists in rural gardens around Bulgaria (Stareva 2016). Other ornamental Asteraceae plants referred to in songs were introduced taxa like Chrysanthemum indicum, Dahlia sp., Tanacetum balsamita and Tagetes sp. The latter, together with other Neotropical plants (Zea mays, Capsicum annum, Dahlia sp., Phaseolus vulgaris and Solanum lycopersicum), was highly praised, and related mostly to festive occasions.

In terms of generalized plant-related mentions, forests (730 mentions) and agricultural landscapes (i.e., field - 605, meadows - 383) appeared similarly valued and revered: the former appear in heroic and haydushki (rebel) songs and the latter are present mainly in ritual and labour/everyday songs. The overarching image of the forest (mostly in mountains) as a shelter ensuring protection against enemies is central to haydushki (rebel) songs. These eventful and mostly historical storylines were emotionally charged with the heroism of the battles prior the Liberation from Ottoman rule (1878) and of the subsequent wars at the beginning of the $20^{\text {th }}$ century. Hence, folk songs organically combined specific details of everyday life with features of the surrounding environment.

In the songs in relation to working activities (e.g., agriculture, trade, household activities, etc.), family-livelihood, historical events and rebel life, tree species are used as references to timber, shelter, clues to water sources, shadow and comfort. Forests, however, considered in their metaphorical projection, give strength to the rebels and reinforce their illegal status, especially in the haydushki (rebel) songs, where a forest stands for the unknown, the distant, the wild and menacing.

\section{Discussion}

Malus domestica, Triticum aestivum and Vitis vinifera were most mentioned in the studied songs being common crops and food plants at the times Bulgarian folk songs were created. The manner in which these three species are being praised could be easily explained with the predominantly agrarian livelihoods in the Pre-modern era, as well as with the similarities related to pre-Christian and Christian symbolism and major crops in this part of Europe. The apple, wheat and grape vine were frequently cited in the folklore of other European cultures, however, comparative studies are limited (Iliev 1892, Georgiev 1976, Kolosova 2005, Seskauskaite \& Gliwa 2010, Herrero \& Cardaño 2015, Vukmanović 2016, Samardžija 2017). In such sense we could recognize these crops as cultural keystone species, according to the concept of Garibaldi \& Turner (2004), of European, however, historical importance. The apple along with fifteen other wild and cultivated Rosaceae species appear in Bulgarian folk songs 


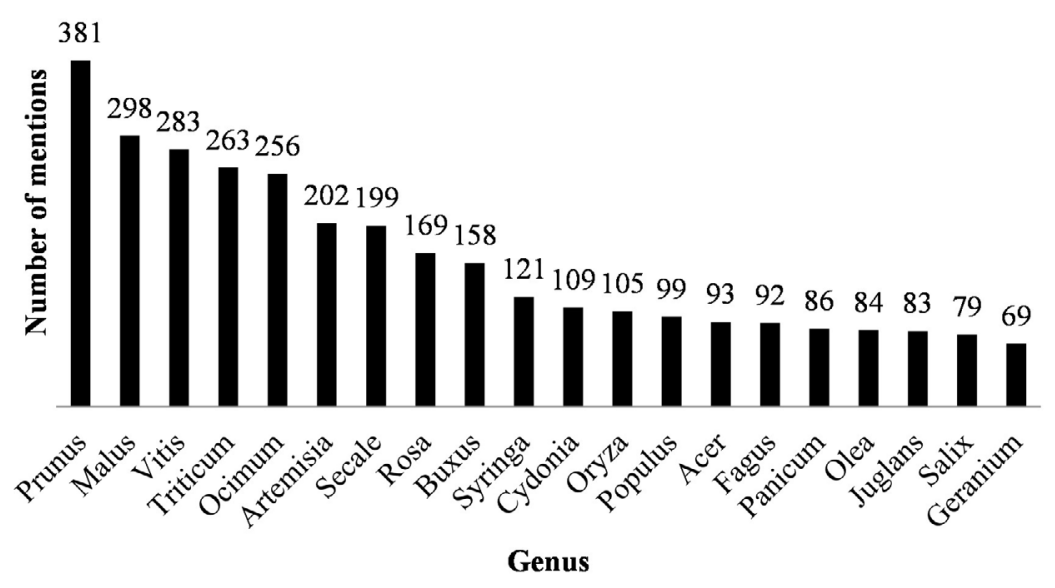

Figure 2. The 20 most prevalent plant genera in Bulgarian folk songs.

in variety of meanings and functions and is involved in a broad range of (still) popular social and cultural contexts in Bulgaria (Georgieva 1993, Baeva 2012). However, only essential-oil bearing Rosa damascena Mill. is viewed as hallmark plant of Bulgaria due to the influencial role of the country in rose oil production worldwide in the last two centuries (Widrlechner 1981, Kovacheva et al. 2010). Multi-purpose and modern applications of the "Bulgarian rose" and high manual work input related to its cultivation were also found to contribute to the process of its heritization (Loulanski \& Loulanski 2014). Latter is not valid for Triticum aestivum, recently produced industrially in highly mechanized manner. Interestingly, when lyrics of the 100 nation-wide favorite Bulgarian folk songs are considered (Bulgarian National radio 2015) the apple still holds the first place of the most frequently mentioned plant species followed by the sweet cherry (data not shown). Hence, a careful collation of ethnographic and recent anthropological sources dealing with nature perception (incl. the animal world, landscapes) is needed before putting certain plant species in the centre point for any industrialized society, if practical at all.

Clearly socio-economic factors played important role in selection of plants cited in Bulgarian folk songs but positive and inspiring emotions were contributing to the "cultural filter" that delineated their appraisal. Allusions to the symbolic role of the grape vine as a spiritual mediator, due to its climbing habit, appear as often as references on the purely utilitarian importance of grape vine as a crop, details of its cultivation and processing practices, including the tools and vessels employed. The frequent reference to vineyards (242) and to wine and spirits production and consumption $(1,171)$ also points to the spread and significance of this crop among Bulgarians, which still permeates local traditions nowadays (Rashkova 2013, Vukov 2013). In contrast, indications for the substantial role of Bulgaria in rice production in Southeastern Europe from $15^{\text {th }}$ till $20^{\text {th }}$ century were not found in the studied songs. The severe infectious diseases outbreaks (mainly malaria) and poor working environment related to rice cultivation were brought as explanation why rice, as a crop, remained unreflected in the Bulgarian culture (Schoeller 2020).

The introduction of American crops was also involved in most positive fashion. While plant-based food was described sparsingly and rooted to the pre-Columbian plant diversity, known to Bulgarians, neophytes like corn, peppers as well as some ornamentals (Tagetes sp., Dahlia sp.) were presented as symbolic plants in religious-themed and marital songs. Capsicum annuum, utilized widely even nowadays in various Bulgarian rituals, was most frequently mentioned (Georgieva 1993). Typically red colored $C$. annuum fruits were cited in wedding ritual songs. However, we also found $C$. annuum mentioned as red pepper powder in lyrics describing a practice of its forging with grinded red tiles. The later was related to a curious belief about how forging this precious spice is calling down plague (Georgieva 1993). Yellow-colored ornamentals and corn brought from the Americas were found to share sunrelated symbolisim ascribed to archeophytes like Triticum sp. and Calendula officinalis. Especially, yellow-orange Tagetes sp. flowers were highly valued in some Bulgarian ritual practices as they symbolize human with blond/ginger hair or with hat. In contrast to American traditions that associate marigolds with death (eher 1968) in Bulgarian 
folk songs marigolds express the lively, youthful energy of a child or young woman.

The very accurate plant representation and considerable richness of wild and cultivated taxa found in Bulgarian folk song infers their potential for development of educational and inspirational materials focused on nature and sustainability. The number of taxa we recorded in Bulgarian folk songs (146) was nearly twice the number of taxa previously registered in the Bulgarian folklore (including songs, fairy tales, legends and sayings) (Iliev 1892, 1893, 1919). Hence, it is probable that other Bulgarian folklore forms may contain undocumented TEK that has been overlooked by anthropological/ethnographical studies. The plant references in the currently studied Bulgarian folk songs were about three times more than those reported by Herrero \& Cardaño (2015) from a territory similar in size in South Europe (Castilla y León, Spain), implying a stronger sensitivity and affiliation of Bulgarians to nature also known as biophilia (Wilson 1984). Similar pervasive connection with nature was usually reported for ethnic groups outside Europe or was relyed through non-poetic folklore forms (Balehegn 2016, Molnár 2017). Strong involvement with nature and especialy plants presented in Bulgarian folk songs showed that Bulgarians perceived their natural environment vividly and in great detail. Thus, current failiures in effective implementation of nature protection legislation in the country should be sought more in political decisions and other factors rather in misperception of Bulgarians about ecosystems (Gocheva et al. 2019).

Bulgarian folk songs are frequently performed on various occasions, such as concerts and festivals held locally and abroad. They are presented also by foreigners, thus gaining wider publicity over a range of media outlets. Hence, performance frequencies of folk songs rich in nature related information, like Bulgarian, would be prospective indicator for assesment of cultural ecosystem services simiraly to crowdsoursed imagery (Luck et al. 2009, Gliozzo et al. 2016, Oteros-Rozas et al. 2018). Yet, further testing of the relevance of such approach is needed. Detailed interpretation (textual/contextual) of their lyrics would assist the transfer of TEK preserved in (Bulgarian) folklore and would enlarge its audiences. Combined with captivating vocal and instrumental performances these texts could be powerful tool to educate and inspire modern audiences.

The innate plant-human connection was represented not only in the images of certain plants but also of those of forests and mountains, which had become notorious both as landscape elements and as shelter for the hayduti (rebels) against the Ottoman rulers in the Late Middle Ages and Premodernity. Mountains and forests were frequently praised in the Revival poetry and eventually acquired a political (state) connotation. Some of these patriotic (folk) songs have retained their significance and are often performed in a romantic and/or political agenda, similarly to the pre-Liberation period at the end of the $19^{\text {th }}$ century. This emotional bondage of Bulgarians with forests/mountains might explain the intensity and extent of civil protests against the destruction of forests for the construction of ski and sea resorts near to and within protected areas (incl. UNESCO Heritage site Pirin National Park - one of the mountains most often extolled in folk songs relevant to plant/nature habitats), which had triggered notable grassroots environmental initiatives like forthenature.org. The organised rallies pressing for environmental justice are inevitably accompanied by nature-praising (folk) songs. A famous exponent of this trend is the ballad named "Hubava si, moya goro!" (You are beautiful, my forest), a song from 1875 based on a lyrical text by the famous Bulgarian poet Lyuben Karavelov, but later on was folklorised. Nowadays, it is the anthem of Bulgarian environmentalist movements. The song compares the freshness of the forest with man's youth and exhibits a degree of love, respect and veneration for the forest, similar to those expressed in the Bulgarian folk songs analysed in this paper. It culminates in
'Whoever casts a look upon you, lives in sorrow ever- after,
Craving in vain to breathe his last breath under your shadows.
And as for the one called to abandon you, He won't be able to forget you for the rest of his life.'

(authors' free translation from Bulgarian).

The powerful stewardship ethics encompassed in this song resonates with the philosophy of many environmental justice movements worldwide and the related protest songs that indigenous peoples use to voice their protests against environmental desecration on their territories (Ramnarine $\underline{2009}$, Lin 2011, Baranovitch 2015). In their despair and pain, caused by the destruction of their beloved lands, environmental protesters search for strength and support in the roots of their musical heritage which speaks not only about the beauty of the land, but also about place-based and culturally-relevant meanings of environmental issues.

In conclusion assessment of TEK in folk songs, tales, legends, etc. and comparative intercultural studies are needed not only to preserve ethnobotanical data. Further documentation and digitalization of folklore would allow 
future exploration and comparative studies would contribute to elaboration of new options to transmmit valuable knowledge locally and globally in the frame of the growing cultural homogenization. Bulgarian folk songs presented wide range of nature-related information that reflected profound connection between plants and humans. Thus, further explorations are needed to rectify reliable and quantifiable data from previously documented poetic folklore so to be used for assessment of cultural significance of species, landscapes and ecosystems.

\section{Acknowledgements}

This study is supported under project DN10/1/2016 "The Garden: Site of Biocultural Diversity and Interdisciplinary Junction" funded by the Bulgarian National Science Fund. The authors hereby express their gratitude to Eng. Plamen Dimitrov (orchidaceae.bg) for his kind help in the preparation of the databases.

\section{Supplementary material}

Supplementary material $\underline{\mathrm{S} 1}$, examples of Bulgarian folk songs presenting various plant taxa. Plant common names in bold font. Supplemental data for this article can be accessed here: https://doi.org/10.17129/botsci.2672

\section{Literature cited}

Adams M, Lükewille A. 2010. The European Environment - state and outlook 2010. Copenhagen: European Environment Agency. ISBN: 978-92-9213-114-2.

Ahmed MM, Das RM, Borthakur SK. 2019. Ethnobotanical study of plants used in Muslim (Pangal/Meitei Pangal) community folklore (folk-songs and folkproverbs) in Manipur, India. International Journal of Plant Science and Ecology 5:1-10.

Ahtarov B, Davidov B, Yavashev A, eds. 1939. Materials for the Bulgarian Botanical Glossary. Sofia: Bulgarian Academy of Sciences Royal Court Printing House.

The Plant list. 2013. Version 1.1. Published on the Internet. http://www.theplantlist.org/ (accessed January 1, 2020).

Arnaudov M, Burin I, Vakarelski H, Dinekov P, Osinin D, eds. 1961-1963. Bulgarian Folklore in Twelve Volumes. Sofia: Bulgarski pisatel.

Aswani S, Lemahieu A, Sauer W. 2018. Global trends of local ecological knowledge and future implications. PLoSONE 13: e0195440. DOI: https://doi.org/10.1371/ journal.pone. 0195440
Baeva V. 2012. The Thread of Life. Between the Fertility Belt and the Holy Girdle of the Virgin. Sofia: Bulgarian Academy of Sciences Publishing. ISBN: 978-954-322485-2

Balehegn M. 2016. Ecological and social wisdom in camel praise poetry sung by Afar nomads of Ethiopia. Journal of Ethnobiology 36: 457-472. DOI: https://doi. org/10.2993/0278-0771-36.2.457

Baranovitch N. 2015. Ecological degradation and endangered ethnicities: China's minority environmental discourses as manifested in popular songs. The Journal of Asian Studies 75: 181-205. DOI: https://doi. org/10.1017/S0021911815001576

Benyei P, Aceituno-Mata L, Calvet-Mir L, Tardío J, Pardode-Santayana M, García-del-Amo D, Rivera-Ferre M, Molina-Simón M, Gras-Mas A, Perdomo-Molina A, Guadilla-Sáez S, Reyes-García V. 2020. Seeds of change: reversing the erosion of traditional agroecological knowledge through a citizen science school program in Catalonia, Spain. Ecology and Society 25:19. DOI: https://doi.org/10.5751/ES-11471-250219

Benítez G, March-Salas M, Villa-Kamel A, ChávesJiménez U, Cariñanos P. 2018. The genus Datura L.(Solanaceae) in Mexico and Spain - ethnobotanical perspective at the interface of medical and illicit uses. Journal of Ethnopharmacology 219: 133-151. DOI: https://doi.org/10.1016/j.jep.2018.03.007

Biserkov V, Gussev C, Popov V, Hibaum G, Roussakova V, Pandurski I, Uzunov Y, Dimitrov M, Tzonev R, Tsoneva S. 2015. Red Data Book of the Republic of Bulgaria.Volume 3. Natural habitats. Sofia: Institute of Biodiversity and Ecosystem Research \& Bulgarian Ministry of Environment and Waters.

Burton R J, Riley M. 2018. Traditional ecological knowledge from the internet? the case of hay meadows in Europe. Land Use Policy 70: 334-346. DOI: https://doi. org/10.1016/j.landusepol.2017.10.014

Chen H, Tao W. 2017. The revival and restructuring of a traditional folk festival: Cultural landscape and memory in Guangzhou, South China. Sustainability 9: 1767. DOI: https://doi.org/10.3390/su9101767

Dénes A, Papp N, Babai D, Czúcz B, Molnár Z. 2012. Wild plants used for food by Hungarian ethnic groups living in the Carpathian Basin. Acta Societatis Botanicorum Poloniae 81: 381-396. DOI: https://doi.org/10.5586/ asbp. 2012.040

Díaz S, Pascual U, Stenseke M, Martín-López B, Watson RT, Molnár Z, Hill R, Chan KMA, Baste IA, Brauman KA, Polasky S, Church A, Lonsdale M, Larigauderie 
A, Leadley PW, van Oudenhoven APE, van der Plaat F, Schröter M, Lavorel S, Aumeeruddy-Thomas Y, Bukvareva E, Davies K, Demissew S, Erpul G, Failler P, Guerra CA, Hewitt CL, Keune H, Lindley S, Shirayama Y. 2018. Assessing nature's contributions to people. Science 359: 270-272. DOI: https://doi.org/10.1126/ science.aap8826

Dudareva M, Goeva N. 2017. White willow in Russian literature: folklore "roots" of image. Journal of Social Studies Education Research 8: 291-299.

Euro+MedPlantBase. 2011. Euro+MedPlantBase - the information resource for Euro-Mediterranean plant diversity. http://ww2.bgbm.org/EuroPlusMed (accessed April 20, 2020).

Ganeva-Raycheva V. 2013. Folklor. In: Otčenášek J., Baeva B, eds. Slovník Termínü Slovesného Folkloru - Bulharsko Praha-Sofia: Etnologickýústav AV ČR, IEFSEM-BAS. pp. 23-27/213-218. ISBN: 978-9548458-43-6.

Garibaldi A, Turner N. 2004. Cultural keystone species: implications for ecological conservation and restoration. Ecology and Society 9: 1. DOI: https://doi. org/10.5751/ES-00669-090301

Georgiev M. 2013. Bulgarian Folk Medicine. Encyclopedia. Sofia: Academic Publishing M. Drinov.ISBN: 978954-322-524-8

Georgiev N. 1976. Bulgarian fFolk Ssong. Art Principles. Structure. Unity. Sofia: Nauka i Izkustvo.

Georgieva I. 1993. Bulgarian Folk Mythology. Sofia: Academic Publishing M. Drinov. ISBN: 978-954-322-568-2

Gerov N. 1895-1904. Glossary of Bulgarian Language (in 5 Volumes). Plovdiv: Suglasie.

Ginchev Ts. 1890. Something on Bulgarian Folk Medicine. Collection of Folk Wisdom, Science and Scriptures 2. Sofia: Ministry of Education. pp. 70-136.

Gliozzo G, Pettorelli N, Hakla M. 2016. Using crowd sourced imagery to detect cultural ecosystem services: a case study in South Wales, UK. Ecology and Society 21: 6. DOI: http://dx.doi.org/10.5751/ES-08436-210306

Gocheva K, Lü Y, Li F, Bratanova-Doncheva S, Chipev N. 2019. Ecosystem restoration in Europe: can analogies to traditional Chinese medicine facilitate the cross-policy harmonization on managing socio-ecological systems? Science of the Total Environment 657: 1553-1567. DOI: https://doi.org/10.1016/j.scitotenv.2018.11.192

Hernández-Morcillo M, Hoberg J, Oteros-Rozas E, Plieninger T, Gómez-Baggethun E, Reyes-García V. 2014. Traditional ecological knowledge in Europe: status quo and insights for the environmental policy agenda. Environment: Science and Policy for Sustainable Development 56: 3-17. DOI: https://doi.org/10.1080/00139157 .2014 .861673

Herrero B, Cardaño M. 2015. Ethnobotany in the folk songs of Castilla y León (Spain). Botanical Sciences 93: 1-12. DOI: https://doi.org/10.17129/botsci.88

Iliev A. 1892. Plant kingdom in the folk poetry, customs, rituals and beliefs of the Bulgarians 1. The Folklore and Ethnography Collection 7: 311-412.

Iliev A. 1893. Plant kingdom in the folk poetry, customs, rituals and beliefs of the Bulgarians 2. The Folklore and Ethnography Collection 9: 409-442.

Iliev A. 1919. Plants according Bulgarian folk views. Collection of Bulgarian Academy of Sciences 18: 94-180

Ivancheva S, Stantcheva N. 2000. Ethnobotanical inventory of medicinal plants in Bulgaria. Journal of Ethnopharmacology 69: 165-172. DOI: https://doi. org/10.1016/s0378-8741(99)00129-4

Ivanova T, Bosseva Y, Ganeva-Raycheva V, Dimitrova D. 2018a. Ethnobotanical knowledge on edible plants used in zelnik pastries from Haskovo province (SouthEast Bulgaria). Phytologia Balcanica 24: 389-395.

Ivanova $T$, Chervenkov $M$, Stoeva $T$, Chervenkov $S$, Bosseva Y, Georgieva A, Tsvetanova E, Alexandrova A, Dimitrova D. 2018b. Samardala: specificities and changes in the ethnobotanical knowledge about Allium siculum subsp. dioscoridis (Sm.) K. Richt. in Bulgaria. Genetic Resources and Crop Evolution 65: 1349-1357. DOI: https://doi.org/10.1007/s10722-018-0618-5

Kalle R, Sõukand R. 2012. Historical ethnobotanical review of wild edible plants of Estonia (1770s-1960s). Acta Societatis Botanicorum Poloniae 81: 271-281. DOI: https://doi.org/10.5586/asbp.2012.033

Kaloyanov A. 1986. Good Hero with Good Horse. Ritual Songs from Asparuhovo village.Varna: Georgy Bakalov.

Kaloyanov A. 1992. Do You Praise Young God? All about Christmas. VelikoTarnovo: Slovo.

Kaufman D, Peycheva L. 2004. Traditional singing and playing. In: Anastassova E, Bratanova R, Georgieva A, Ivanova $\mathrm{M}$, Kaufman $\mathrm{D}$, Krastanova $\mathrm{K}$, Lozanova $\mathrm{S}$, Mateeva V, Peycheva L, Santova M, Stanoeva I, Shtarbanova A, eds. Living Human Treasures - Bulgaria. Sofia: Marin Drinov Academic Publishing, pp. 308-334.

Kaufman N. 2001. L'ethnomusicologie Bulgare. Ethnologie Française 31: 219-227.

Kim G, Vaswani R T, Kang W, Nam M, Lee D. 2017. Enhancing ecoliteracy through traditional ecological 
knowledge in proverbs. Sustainability 9: 1182. DOI: https://doi.org/doi:10.3390/su9071182

Kitanov B. 1953. Materials on utilization of wild plants in the national economy. Bulletin of Institute of Botany, Bulgarian Academy of Sciences 3: 257-260.

Kolosova V. B. 2005. Name-text-ritual: the role of plant characteristics in Slavic folk medicine. Folklorica 10: 44-61.

Kovacheva N, Rusanov K, Atanassov I. 2010. Industrial cultivation of oil bearing rose and rose oil production in Bulgaria during 21st century, directions and challenges. Biotechnology \& Biotechnological Equipment 24: 1793-1798. DOI: https://doi.org/10.2478/V10133010-0032-4

Kozarov P. 1925. Bulgarian Plant Folk Names.Collection of Bulgarian Academy of Sciences 20: 1-90.

Kujawska M, Klepacki P, Łuczaj Ł. 2017. Fischer's plants in folk beliefs and customs: a previously unknown contribution to the ethnobotany of the Polish-LithuanianBelarusian borderland. Journal of Ethnobiology and Ethnomedicine 13: 20. DOI: https://doi.org/10.1186/ s13002-017-0149-8

Lange BR. 2018. Local Fusions: Folk Music Experiments in Central Europe at the Millennium. Oxford: Oxford University Press. ISBN: 978-0190245368

Leonti M. 2011. The future is written: impact of scripts on the cognition, selection, knowledge and transmission of medicinal plant use and its implications for ethnobotany and ethnopharmacology. Journal of Ethnopharmacology 134: 542-555. DOI: https://doi.org/10.1016/j. jep.2011.01.017

Lin TH. 2011. Mountain songs, Hakka songs, protest songs: a case study of two Hakka singers from Taiwan. Asian Music 42: 85-122.

Loulanski V, Loulanski, T. 2014. The heritization of Bulgarian rose. Acta Geographica Slovenica 54: 401410. DOI: https://doi.org/10.3986/AGS54408

Luck GW, Harrington R, Harrison PA, Kremen C, Berry PM, Bugter R, Dawson TP, De Bello F, Díaz S, Feld CK, Haslett JR. 2009. Quantifying the contribution of organisms to the provision of ecosystem services. Bioscience 59: 223-235. DOI: https://doi.org/10.1525/ bio.2009.59.3.7

Łuczaj Ł. 2009. Primroses versus spruces: cultural differences between flora depicted in British and Polish children's books. Ethnobotany Research and Applications 7: 115-121. DOI: https://doi.org/10.17348/era.7.0.115$\underline{121}$

Łuczaj Ł. 2012. A relic of medieval folklore: Corpus
Christi Octave herbal wreaths in Poland and their relationship with the local pharmacopoeia. Journal of Ethnopharmacology 142: 228-240. DOI: https://doi. org/10.1016/j.jep.2012.04.049

Mac Coitir N. 2016. Ireland's Trees-Myths, Legends \& Folklore. $2^{\text {nd }}$ Edition. Cork: Collins Press. ISBN: 978184-889-248-4.

Mekbib F. 2009. Folksong based appraisal of bioecocultural heritage of sorghum (Sorghum bicolor (L.) Moench): a new approach in ethnobiology. Journal of Ethnobiology and Ethnomedicine 5: 19. DOI: https:// doi.org/10.1186/1746-4269-5-19

Mollov T. 2006-2017. Bulgarian Folk Motifs. Ballads. Varna: LiterNet. ISBN: 978-954-304-227-2

Molnár Z. 2017. "I See the grass through the mouths of my animals" - folk indicators of pasture plants used by traditional steppe herders. Journal of Ethnobiology 37: 522541. DOI: https://doi.org/10.2993/0278-0771-37.3.522

Nedelcheva A. 2013. An ethnobotanical study of wild edible plants in Bulgaria. Eurasian Journal of Biosciences 7: 77-94.

Nedelcheva A, Dogan Y. 2011. Usage of plants for weather and climate forecasting in Bulgarian folk traditions. Indian Journal of Traditional Knowledge 10: 91-95.

Nedelcheva A, Dogan Y, Obratov-Petkovic D, Padure IM. 2011. The traditional use of plants for handicrafts in Southeastern Europe. Human Ecology 39: 813-828. DOI: https://doi.org/10.1007/s10745-011-9432-9

Nedkov S, Borisova B, Koulov B, Zhiyanski M, Bratanova-Doncheva S, Nikolova M, Kroumova J. 2018. Towards integrated mapping and assessment of ecosystems and their services in Bulgaria: The Central Balkan case study. One Ecosystem 3: e25428. DOI: https://doi. org/10.3897/oneeco.3.e25428

Neher RT. 1968. The ethnobotany of Tagetes. Economic Botany 22: 317-325. DOI: https://doi.org/10.1007/ $\underline{\mathrm{BF} 02908126}$

Oteros-Rozas E, Martín-López B, Fagerholm N, Bieling $\mathrm{C}$, Plieninger T. 2018. Using social media photos to explore the relation between cultural ecosystem services and landscape features across five European sites. Ecological Indicators 94: 74-86. DOI: https://doi. org/10.1016/j.ecolind.2017.02.009

Pandey D, Pandey VC. 2016. Sacred plants from ancient to modern era: traditional worshipping towards plants conservation. Tropical Plant Research 3: 136-141.

Petkov V. 1986. Bulgarian traditional medicine: a source of ideas for phytopharmacological investigations. Jour- 
nal of Ethnopharmacology 15: 121-132. DOI: https:// doi.org/10.1016/0378-8741(86)90149-2

Peycheva L. 2015. Art-folk Musical hybrids from Bulgaria: historical perspective. In: Keller I, Jacobs F. Das Reine und das Vermischte-15 Jahredanach. Muenster: Waxmann pp. 129-139. ISBN: 978-3-83093255-0

Pieroni A, Quave C, Giusti M, Papp N. 2012. "We are Italians!": The hybrid ethnobotany of a Venetian diaspora in Eastern Romania. Human Ecology 40: 435-451. DOI: https://doi.org/10.1007/s10745-0129493-4

Quave CL, Pardo-de-Santayana M, Pieroni A. 2012. Medical ethnobotany in Europe: from field ethnography to a more culturally sensitive evidence-based CAM? Evidence-based Complementary and Alternative Medicine 2012: 156846. DOI: https://doi. org/10.1155/2012/156846

Ramet A, Benyei P, Parada M, Aceituno-Mata L, Garcíadel-Amo D, Reyes-García V. 2018. Grandparents' proximity and children's traditional medicinal plant knowledge: insights from two schools in intermediate-rural Spain. Journal of Ethnobiology 38: 187-204. DOI: https://doi.org/10.2993/0278-0771-38.2.187

Ramnarine TK. 2009. Acoustemology, indigeneity, and joikin Valkeapää'ssymphonic activism: views from Europe's arctic fringes for environmental ethnomusicology. Ethnomusicology 53: 187-217.

Rashkova N. 2013. The Bulgarian wine feast: tradition and transformation. Acta Ethnographica Hungarica 58: $347-357$.

Rice T. 2017. Modeling Ethnomusicology. New York: Oxford University Press. ISBN: 978-019-061-689-2

Samardžija SD. 2017. The most beautiful flower. The symbolism of wheat in Serbian folk poetry and prose. In: Karanovich Z, ed. Peony Mountain (Plants and Herbs in the Traditional Slavic Culture). Belgrade: University library Svetozar Markovich, pp. 9-23.

Schirpke U, Meisch C, Tappeiner U. 2018. Symbolic species as a cultural ecosystem service in the European Alps: insights and open issues. Landscape Ecology 33: 711-730. DOI: https://doi.org/10.1007/s10980-0180628-X

Schoeller M. 2020. This Unknown Land. Sofia: Zhanet-45 Publishing. ISBN: 978-619-186-543-7

Seskauskaite D, Gliwa B. 2010. The botanical identity and cultural significance of Lithuanian jovaras. In: PardoDe-Santayana M, Pieroni A, Puri R, eds. Ethnobotany in the New Europe: People, Health and Wild Plant
Resources, New York: Berghahn Books, pp 246-262. ISBN: 978-1-84545-456-2

Shukla S, Barkman J, Patel K. 2017. Weaving indigenous agricultural knowledge with formal education to enhance community food security: school competition as a pedagogical space in rural Anchetty. India. Pedagogy, Culture and Society 25: 87-103. DOI: https://doi.org/1 $\underline{0.1080 / 14681366.2016 .1225114}$

Silva TCD, Medeiro, PM, Balcázar AL, Sousa TADA, Pirondo A, Medeiros MFT. 2014. Historical ethnobotany: an overview of selected studies. Ethnobiology and Conservation 3: 4. DOI: https://doi. org/10.15451/ec2014-6-3.4-1-12

Simoons FJ. 1998. Plants of Life, Plants of Death. Madison: University of Wisconsin Press. ISBN: 9780756763688

Stareva L. 2016. Bulgarian Fortune Rituals. Sofia: Trud Publishing. ISBN: 9545285494

Stoyanov N, Kitanov B. 1960. Wild Useful Plants in Bulgaria. Sofia: Bulgarian Academy of Sciences.

Stranski I. 1929. Ueber den Spelzweizen in Bulgarien. Bulletin de la Societe Botanique de Bulgarie 3: 171277.

Svanberg I, Łuczaj Ł. 2014. Activity contexts and biocultural domains. In: Svanberg I, Łuczaj Ł, eds. Pioneers in European Ethnobiology. Uppsala: Uppsala University, pp. 9-26. ISBN: 978-91-554-8844-4

Svanberg I, Łuczaj Ł, Pardo-De-Santayana M, Pieroni A, Anderson E, Adams K, Turner N. 2011. History and current trends of ethnobiological research in Europe. Ethnobiology 191: 214. DOI: https://doi. org/10.1002/9781118015872

Thiselton-Dyer T. 1889. The Folk-Lore of Plants. Create Space Independent Publishing. ISBN: 978-1530349333

Tolstaia S. 2018. Plant symbolics in Polish folk traditions. Grains. Rocznik Slawistyczny 68: 189-197. DOI: https://doi.org/10.24425/rslaw.2018.124602

Urumov I. 1926. Materials on Bulgarian folk medicines. Collection of Bulgarian Academy of Sciences 22: $1-128$.

Vakarelski H. 1977. Ethnography of Bulgaria. Sofia: Nauka i Izkustvo.

Vladimirov V. Petrova A. eds. 2017. Ecosystems with Rare Vegetation outside NATURA 2000 Network in Bulgaria. Sofia: Institute of Biodiversity and Ecosystem Research, Bulgarian Academy of Sciences. ISBN: 987-954-9746-38-9

Vukmanović A. 2016. Marvellous plants in lyrical folk songs. In: Karanović Z, Dražić J, eds. Plants 


\section{Ethnobotany of Bulgarian folk songs}

and Herbs in Traditional Serbian Culture. Beograd: Serbian Folklorist Association, University Library Svetozar Marković, pp.55-66. ISBN: 978-86-6065$172-5$

Vukov N. 2013. Wine as a signifier of kinship in Bulgarian folklore epics. Acta Ethnographica Hungarica, 58: 389-396.

Watts D. 2007. Dictionary of Plant Lore. Burlington: Academic Press. ISBN: 978-01-2374-086-1

Associate editor: Pedro Luis Valverde

Author contributions: TI, writing analysis, manuscript preparation; VG-R, data collection and collation, manuscriprt preparation; YB, data analysis, manuscript preparation; $\mathrm{DD}$, writing analysis, manuscript editing.
Widrlechner MP. 1981. History and utilization of Rosa damascena. Economic Botany 35: 42-58. DOI: https:// doi.org/10.1007/BF02859214

Wilks L, Quinn B. 2016. Linking social capital, cultural capital and heterotopia at the folk festival. Journal of comparative research in anthropology and sociology 7: 23-39.

Wilson E. 1984. Biophilia. Cambridge: Harvard University Press. ISBN 0-674-07442-4 
Appendix 1. Plant taxa mentioned in Bulgarian folk songs.

\begin{tabular}{|c|c|c|c|c|c|c|c|c|c|c|c|c|c|}
\hline \multirow[t]{2}{*}{ Family } & \multirow[t]{2}{*}{ Taxon } & \multirow[t]{2}{*}{ Common name } & \multirow[t]{2}{*}{ Setting } & \multirow[t]{2}{*}{ Origin } & \multicolumn{8}{|c|}{ Song type } & \multirow[t]{2}{*}{ Total } \\
\hline & & & & & $\begin{array}{l}\text { Family } \\
\text { liveli- } \\
\text { hood }\end{array}$ & $\begin{array}{l}\text { Haydu- } \\
\text { shki } \\
\text { (rebel) }\end{array}$ & Heroic & $\begin{array}{c}\text { Histo- } \\
\text { rical }\end{array}$ & Labour & Mythic & Ritual & Msc. & \\
\hline Aceraceae & Acer sp. & Maple & $\mathrm{w}$ & $\mathrm{i}$ & 1 & 1 & & 1 & 3 & 5 & 12 & 70 & 93 \\
\hline Adoxaceae & Viburnum opulus L. & Guelder rose & w & $\mathrm{i}$ & 2 & & & & & & & & 2 \\
\hline Adoxaceae & Sambucus ebulus L. & European elder & $\mathrm{w}$ & $\mathrm{i}$ & & & & & & & 2 & 10 & 12 \\
\hline Amaranthaceae & Galanthus sp. & Snowdrop & $\mathrm{c} / \mathrm{w}$ & $\mathrm{i}$ & & & & & & & & 2 & 2 \\
\hline Amaranthaceae & Celosia argentea $\mathrm{L}$. & $\begin{array}{l}\text { Plumed } \\
\text { cockscomb }\end{array}$ & $\mathrm{c}$ & $\mathrm{a}$ & 4 & & & & 2 & 1 & 7 & 1 & 15 \\
\hline Amaryllidaceae & Allium sp. & Allium & $\mathrm{c} / \mathrm{w}$ & $\mathrm{i}$ & & & 1 & & & 1 & 2 & & 4 \\
\hline Amaryllidaceae & Allium sativum $\mathrm{L}$. & Garlic & $\mathrm{c}$ & $\mathrm{a}$ & & & & & 1 & & & & 1 \\
\hline Amaryllidaceae & Allium cepa $\mathrm{L}$. & Onion & $\mathrm{c}$ & $\mathrm{a}$ & 1 & & & & & & & & 1 \\
\hline Apiaceae & Conium maculatum $\mathrm{L}$. & Hemlock & $\mathrm{w}$ & $\mathrm{i}$ & & & & 1 & & & & 1 & 2 \\
\hline Apocynaceae & Vinca sp. & Periwinkle & $\mathrm{c} / \mathrm{w}$ & $\mathrm{i}$ & & & & & & & 1 & 2 & 3 \\
\hline Aquifoliaceae & Ilex aquifolium $\mathrm{L}$. & Common holly & w & $\mathrm{i}$ & & & & & & & 1 & & 1 \\
\hline Araliaceae & Hedera helix $\mathrm{L}$. & Common ivy & w & $\mathrm{i}$ & 1 & & & & & 2 & 5 & 18 & 26 \\
\hline Asparagaceae & Hyacinthus orientalis L. & $\begin{array}{l}\text { Common } \\
\text { hyacinth }\end{array}$ & $\mathrm{c}$ & $\mathrm{a}$ & 3 & & & & & & & 12 & 15 \\
\hline Asteraceae & Zinnia elegans $\mathrm{L}$. & Common zinnia & $\mathrm{c}$ & a & 1 & & & & & & & & 1 \\
\hline Asteraceae & Tussilago farfara $\mathrm{L}$. & Coltsfoot & $\mathrm{w}$ & $\mathrm{i}$ & & & & & & 1 & & & 1 \\
\hline Asteraceae & Tanacetum vulgare $\mathrm{L}$. & Common tansy & $\mathrm{w}$ & $\mathrm{i}$ & 1 & & & & 2 & 5 & 1 & 1 & 10 \\
\hline Asteraceae & Tanacetum balsamita $\mathrm{L}$. & Costmary & $\mathrm{c}$ & $\mathrm{a}$ & & & & & & 1 & 2 & & 3 \\
\hline Asteraceae & Tagetes sp. & Marigold & $\mathrm{c}$ & $\mathrm{n}$ & & 1 & & & & 1 & & & 2 \\
\hline Asteraceae & $\begin{array}{l}\text { Helichrysum arenarium (L.) } \\
\text { Moench }\end{array}$ & Dwarf everlast & $\mathrm{w}$ & $\mathrm{i}$ & & & & & & & 1 & & 1 \\
\hline Asteraceae & Dahlia sp. & Dahlia & $\mathrm{c}$ & $\mathrm{n}$ & & & & & 1 & & & & 1 \\
\hline Asteraceae & Cirsium arvense (L.) Scop. & Creeping thistle & $\mathrm{w}$ & $\mathrm{i}$ & & & & & & & 1 & & 1 \\
\hline Asteraceae & Chrysanthemum indicum $\mathrm{L}$. & $\begin{array}{l}\text { Indian } \\
\text { chrysanthemum }\end{array}$ & $\mathrm{c}$ & $\mathrm{a}$ & & & & & 1 & & & & 1 \\
\hline Asteraceae & Calendula officinalis $\mathrm{L}$. & $\begin{array}{l}\text { Common } \\
\text { marigold }\end{array}$ & $\mathrm{c}$ & $\mathrm{a}$ & & & & & 1 & & 3 & 1 & 5 \\
\hline Asteraceae & Artemisia sp. & Mugwort & $\mathrm{w}$ & $\mathrm{i}$ & 2 & & 1 & & 1 & 1 & 4 & 189 & 198 \\
\hline
\end{tabular}




\begin{tabular}{|c|c|c|c|c|c|c|c|c|c|c|c|c|c|}
\hline \multirow[t]{2}{*}{ Family } & \multirow[t]{2}{*}{ Taxon } & \multirow[t]{2}{*}{ Common name } & \multirow[t]{2}{*}{ Setting } & \multirow[t]{2}{*}{ Origin } & \multicolumn{8}{|c|}{ Song type } & \multirow[t]{2}{*}{ Tota } \\
\hline & & & & & $\begin{array}{c}\text { Family } \\
\text { liveli- } \\
\text { hood }\end{array}$ & $\begin{array}{l}\text { Haydu- } \\
\text { shki } \\
\text { (rebel) }\end{array}$ & Heroic & $\begin{array}{c}\text { Histo- } \\
\text { rical }\end{array}$ & Labour & Mythic & Ritual & Msc. & \\
\hline Asteraceae & Artemisia campestris $\mathrm{L}$. & Field mugwort & $\mathrm{w}$ & $\mathrm{i}$ & & & & & 1 & & & 2 & 3 \\
\hline Asteraceae & Artemisia alba Turra & White mugwort & $\mathrm{w}$ & $\mathrm{i}$ & & & & & & & 1 & & 1 \\
\hline Betulaceae & Corylus avellana $\mathrm{L}$. & Common hazel & $\mathrm{w}$ & $\mathrm{i}$ & 1 & & & & & 1 & 1 & 34 & 37 \\
\hline Betulaceae & Carpinus sp. & Hornbeam & $\mathrm{w}$ & $\mathrm{i}$ & & 1 & & & & & & 1 & 2 \\
\hline Betulaceae & Betula pendula Roth & Silver birch & $\mathrm{w}$ & $\mathrm{i}$ & & & & & & & & 2 & 2 \\
\hline Betulaceae & Alnus glutinosa (L.) Gaertn. & Common alder & $\mathrm{w}$ & $\mathrm{i}$ & & & & & 1 & 2 & 2 & 1 & 6 \\
\hline Boraginaceae & Symphytum officinale $\mathrm{L}$. & Common comfrey & w & $\mathrm{i}$ & 1 & & & & & & & & 1 \\
\hline Buxaceae & Buxus sempervirens $\mathrm{L}$. & $\begin{array}{l}\text { Common box/ } \\
\text { boxwood }\end{array}$ & $\mathrm{c}$ & $\mathrm{a}$ & 1 & 2 & 1 & & 2 & 3 & 11 & 138 & 158 \\
\hline Cannabaceae & Cannabis sativa $\mathrm{L}$. & Hemp & $\mathrm{c}$ & $\mathrm{a}$ & & & 1 & & & & 2 & 4 & 7 \\
\hline Caryophyllaceae & Dianthus sp. & Carnation & $\mathrm{c}$ & $\mathrm{i} / \mathrm{a}$ & & & & 1 & & & & 12 & 13 \\
\hline Caryophyllaceae & Dianthus caryophyllus $\mathrm{L}$. & Carnation & $\mathrm{c}$ & $\mathrm{a}$ & 2 & & & 1 & & 1 & 2 & & 6 \\
\hline Cornaceae & Cornus mas $\mathrm{L}$. & European cornel & $\mathrm{w}$ & $\mathrm{i}$ & 3 & & & 1 & 2 & & 3 & 40 & 49 \\
\hline Cucurbitaceae & Cucurbita sp. & Pumpkin & $\mathrm{c}$ & $\mathrm{a}$ & & & & & & & 1 & & 1 \\
\hline Cucurbitaceae & $\begin{array}{l}\text { Citrullus lanatus (Thunb.) } \\
\text { Matsum. \& Nakai }\end{array}$ & Watermelon & $\mathrm{c}$ & $\mathrm{a}$ & 1 & & & & & & & & 1 \\
\hline Dipsacaceae & Dipsacus laciniatus $\mathrm{L}$. & Cutleaf teasel & $\mathrm{w}$ & $\mathrm{i}$ & & & & & & 1 & & & 1 \\
\hline Ericaceae & Erica arborea $\mathrm{L}$. & Tree heather & $\mathrm{w}$ & $\mathrm{i}$ & & & & & 1 & & & & 1 \\
\hline Fabaceae & Vicia faba $\mathrm{L}$. & Faba bean & $\mathrm{c}$ & $\mathrm{a}$ & & & & & 1 & & & & 1 \\
\hline Fabaceae & Trifolium sp. & Clover & $\mathrm{w}$ & $\mathrm{i}$ & 1 & & 1 & & 7 & 1 & 3 & 31 & 44 \\
\hline Fabaceae & Trifolium pratense $\mathrm{L}$. & Red clover & $\mathrm{w}$ & $\mathrm{i}$ & & & & & & 1 & & & 1 \\
\hline Fabaceae & $\begin{array}{l}\text { Spartium scoparium/ } \\
\text { junceum L.L. }\end{array}$ & $\begin{array}{l}\text { Common broom/ } \\
\text { Spanish broom }\end{array}$ & w & $\mathrm{i}$ & & & & & 1 & & & 1 & 2 \\
\hline Fabaceae & Robinia pseudoacacia $\mathrm{L}$. & Black locust & w & $\mathrm{n}$ & & & & & & 2 & & 1 & 3 \\
\hline Fabaceae & Phaseolus vulgaris $\mathrm{L}$. & Common bean & $\mathrm{c}$ & $\mathrm{n}$ & & & & & 1 & & & & 1 \\
\hline Fabaceae & Melilotus sp. & Melilot & w & $\mathrm{i}$ & & & & & & 6 & & & 6 \\
\hline Fabaceae & $\begin{array}{l}\text { Melilotus officinalis (L.) } \\
\text { Pall. }\end{array}$ & $\begin{array}{l}\text { Yellow sweet } \\
\text { clover }\end{array}$ & $\mathrm{w}$ & $\mathrm{i}$ & & & & & & 2 & & 2 & 4 \\
\hline Fabaceae & Melilotus albus Medik. & Honey clover & $\mathrm{w}$ & $\mathrm{i}$ & & & & & & 1 & & & 1 \\
\hline Fabaceae & Lens culinaris Medik. & Lentil & $\mathrm{c}$ & $\mathrm{a}$ & 1 & & & & & & 2 & & 3 \\
\hline
\end{tabular}




\begin{tabular}{|c|c|c|c|c|c|c|c|c|c|c|c|c|c|}
\hline \multirow[t]{2}{*}{ Family } & \multirow[t]{2}{*}{ Taxon } & \multirow[t]{2}{*}{ Common name } & \multirow[t]{2}{*}{ Setting } & \multirow[t]{2}{*}{ Origin } & \multicolumn{8}{|c|}{ Song type } & \multirow[t]{2}{*}{ Total } \\
\hline & & & & & $\begin{array}{c}\text { Family } \\
\text { liveli- } \\
\text { hood }\end{array}$ & $\begin{array}{c}\text { Haydu- } \\
\text { shki } \\
\text { (rebel) }\end{array}$ & Heroic & $\begin{array}{l}\text { Histo- } \\
\text { rical }\end{array}$ & Labour & Mythic & Ritual & Msc. & \\
\hline Fabaceae & $\begin{array}{l}\text { Lathyrus tuberosus/vernus } \\
\text { L./(L.) Bernh. }\end{array}$ & $\begin{array}{l}\text { Tuberous pea/ } \\
\text { spring vetchling }\end{array}$ & $\mathrm{w}$ & $\mathrm{i}$ & & & & & & & 1 & & 1 \\
\hline Fabaceae & Lathyrus sylvestris L. & $\begin{array}{l}\text { Narrow-leaved } \\
\text { everlasting-pea }\end{array}$ & $\mathrm{w}$ & $\mathrm{i}$ & & & & & & 1 & & & 1 \\
\hline Fabaceae & Cicer arietinum $\mathrm{L}$. & Chickpea & $\mathrm{c}$ & a & 1 & & & & & 1 & & & 2 \\
\hline Fagaceae & Quercus sp. & Oak & $\mathrm{w}$ & $\mathrm{i}$ & 3 & & & & & 2 & 2 & 7 & 14 \\
\hline Fagaceae & $\begin{array}{l}\text { Quercus petraea (Matt.) } \\
\text { Liebl. }\end{array}$ & Sessile oak & $\mathrm{w}$ & $\mathrm{i}$ & & & & & & & 1 & & 1 \\
\hline Fagaceae & Quercus cerris $\mathrm{L}$. & Turkey oak & $\mathrm{w}$ & $\mathrm{i}$ & & & & & 1 & & & & 1 \\
\hline Fagaceae & Fagus sylvatica $\mathrm{L}$. & European beech & $\mathrm{w}$ & $\mathrm{i}$ & 3 & 3 & & 2 & & 2 & 1 & 81 & 92 \\
\hline Gentianaceae & Gentiana sp. & Gentian & $\mathrm{w}$ & $\mathrm{i}$ & 1 & & & & & 3 & & 5 & 9 \\
\hline Gentianaceae & Gentiana pneumonanthe $\mathrm{L}$. & Marsh gentian & $\mathrm{w}$ & $\mathrm{i}$ & & & & 1 & & 4 & & 1 & 6 \\
\hline Gentianaceae & Gentiana lutea $\mathrm{L}$. & $\begin{array}{l}\text { Great yellow } \\
\text { gentian }\end{array}$ & $\mathrm{w}$ & $\mathrm{i}$ & & & & & & 1 & & & 1 \\
\hline Geraniaceae & Geranium macrorrhizum L. & Bigroot geranium & $\mathrm{c} / \mathrm{w}$ & $\mathrm{i}$ & & & & & 1 & 6 & 9 & 53 & 69 \\
\hline Iridaceae & Iris sp. & Iris & $\mathrm{c} / \mathrm{w}$ & $\mathrm{i}$ & 1 & & & & 1 & 1 & 4 & & 7 \\
\hline Iridaceae & Iris $\times$ germanica $\mathrm{L}$. & German iris & $\mathrm{c}$ & $\mathrm{a}$ & 1 & & & & & & 2 & 12 & 15 \\
\hline Iridaceae & Crocus sp. & Saffron & w & $\mathrm{i}$ & 1 & & & & & & 1 & 1 & 3 \\
\hline Juglandaceae & Juglans regia $\mathrm{L}$. & Common walnut & $\mathrm{c}$ & $\mathrm{i}$ & 4 & 1 & & 1 & 8 & 2 & 5 & 62 & 83 \\
\hline Lamiaceae & Thymus sp. & Thyme & $\mathrm{w}$ & $\mathrm{i}$ & & & & & & & 1 & & 1 \\
\hline Lamiaceae & Satureja sp. & Savory & $\mathrm{w}$ & $\mathrm{i}$ & & & & & & 1 & & 2 & 3 \\
\hline Lamiaceae & Satureja hortensis L. & Winter savory & $\mathrm{c}$ & $\mathrm{a}$ & & & & & & & 1 & & 1 \\
\hline Lamiaceae & Ocimum basilicum L. & Sweet basil & $\mathrm{c}$ & $\mathrm{a}$ & 14 & 1 & 1 & 3 & 9 & 7 & 36 & 185 & 256 \\
\hline Lamiaceae & Melissa officinalis $\mathrm{L}$. & Lemon balm & $\mathrm{w}$ & $\mathrm{i}$ & & & & & & 1 & & & 1 \\
\hline Lauraceae & Laurus nobilis L. & Bay tree & $\mathrm{c}$ & $\mathrm{i}$ & 1 & 2 & & 1 & 2 & 1 & & 1 & 8 \\
\hline Liliaceae & Tulipa $\mathrm{sp}$. & Tulip & $\mathrm{c} / \mathrm{w}$ & $\mathrm{i} / \mathrm{a}$ & 3 & 1 & & & & & 1 & 15 & 20 \\
\hline Liliaceae & Ruscus aculeatus L. & Butcher's-broom & $\mathrm{w}$ & $\mathrm{i}$ & & & & & & 1 & & & 1 \\
\hline Liliaceae & Lilium candidum $\mathrm{L}$. & Madonna lily & $\mathrm{c}$ & $\mathrm{a}$ & & & & & 1 & & & 2 & 3 \\
\hline Linaceae & Linum usitatissimum L. & Common flax & $\mathrm{c}$ & a & & & & & 2 & & 2 & & 4 \\
\hline Lythraceae & Punica granatum $\mathrm{L}$. & Pomegranate & $\mathrm{c}$ & $\mathrm{a}$ & & & & 1 & & 1 & 1 & & 3 \\
\hline
\end{tabular}




\begin{tabular}{|c|c|c|c|c|c|c|c|c|c|c|c|c|c|}
\hline \multirow[t]{2}{*}{ Family } & \multirow[t]{2}{*}{ Taxon } & \multirow[t]{2}{*}{ Common name } & \multirow[t]{2}{*}{ Setting } & \multirow[t]{2}{*}{ Origin } & \multicolumn{8}{|c|}{ Song type } & \multirow[t]{2}{*}{ Total } \\
\hline & & & & & $\begin{array}{c}\text { Family } \\
\text { liveli- } \\
\text { hood }\end{array}$ & $\begin{array}{c}\text { Haydu- } \\
\text { shki } \\
\text { (rebel) }\end{array}$ & Heroic & $\begin{array}{c}\text { Histo- } \\
\text { rical }\end{array}$ & Labour & Mythic & Ritual & Msc. & \\
\hline Malvaceae & Gossypium sp. & Cotton & $\mathrm{c}$ & $\mathrm{a}$ & 2 & & & & 1 & & & & 3 \\
\hline Melanthiaceae & Veratrum sp. & False hellebore & $\mathrm{w}$ & $\mathrm{i}$ & & & & & & & 1 & & 1 \\
\hline Moraceae & Morus sp. & Mulberry & $\mathrm{c}$ & $\mathrm{a}$ & & & & & & 1 & & 21 & 22 \\
\hline Moraceae & Morus alba $\mathrm{L}$. & White mulberry & $\mathrm{c}$ & a & & & & & 1 & & & & 1 \\
\hline Moraceae & Ficus carica $\mathrm{L}$. & Common fig & $\mathrm{c} / \mathrm{w}$ & $\mathrm{i}$ & & & & 1 & & & & & 1 \\
\hline Oleaceae & Syringa vulgaris $\mathrm{L}$. & Common lilac & $\mathrm{c} / \mathrm{w}$ & $\mathrm{i}$ & 6 & & & & 1 & 1 & 5 & 108 & 121 \\
\hline Oleaceae & Olea europaea $\mathrm{L}$. & Olive & $\mathrm{c}$ & $\mathrm{i}$ & 1 & 1 & & & & 1 & 1 & 80 & 84 \\
\hline Oleaceae & Fraxinus ornus $\mathrm{L}$. & Manna ash & $\mathrm{w}$ & $\mathrm{i}$ & 1 & & & & & & & & 1 \\
\hline Oleaceae & Fraxinus excelsior L. & Common ash & $\mathrm{w}$ & $\mathrm{i}$ & & & & & & & 2 & & 2 \\
\hline Paeoniaceae & Paeonia sp. & Peony & $\mathrm{c} / \mathrm{w}$ & $\mathrm{i} / \mathrm{a}$ & & & & & 2 & & & 15 & 17 \\
\hline Paeoniaceae & Paeonia peregrina Mill. & Balkan peony & $\mathrm{w}$ & $\mathrm{i}$ & 2 & & & & 1 & & & & 3 \\
\hline Papaveraceae & Papaver sp. & Poppy & $\mathrm{w}$ & $\mathrm{i}$ & & & & & & & 1 & & 1 \\
\hline Papaveraceae & Papaver rhoeas $\mathrm{L}$. & Common poppy & w & $\mathrm{i}$ & & & & & 1 & & & & 1 \\
\hline Pedaliaceae & Sesamum indicum $\mathrm{L}$. & Sesame & $\mathrm{c}$ & a & & & & 1 & & & & & 1 \\
\hline Pinaceae & Pinus sp. & Pine & $\mathrm{w}$ & $\mathrm{i}$ & 3 & & & & 1 & 6 & 4 & & 14 \\
\hline Pinaceae & Abies alba Mill. & $\begin{array}{l}\text { European silver } \\
\text { fir }\end{array}$ & $\mathrm{w}$ & $\mathrm{i}$ & 4 & 3 & & & 1 & 7 & 10 & & 25 \\
\hline Piperaceae & Piper nigrum $\mathrm{L}$. & Black pepper & ip & & 1 & & & 1 & & & & & 2 \\
\hline Platanaceae & Platanus orientalis L. & $\begin{array}{l}\text { Old World } \\
\text { sycamore }\end{array}$ & $\mathrm{w}$ & $\mathrm{i}$ & & & & & 1 & & & 1 & 2 \\
\hline Poaceae & Zea mays $\mathrm{L}$. & Corn & $\mathrm{c}$ & $\mathrm{n}$ & & 1 & & 1 & 2 & & 1 & 11 & 16 \\
\hline Poaceae & Triticum sp. & Wheat & $\mathrm{c}$ & a & 6 & 9 & 4 & 8 & 23 & 11 & 31 & 171 & 263 \\
\hline Poaceae & Stipa sp. & Feather grass & $\mathrm{w}$ & $\mathrm{i}$ & & & & & & & 1 & 4 & 5 \\
\hline Poaceae & Secale cereale $\mathrm{L}$. & Rye & $\mathrm{c}$ & $\mathrm{a}$ & 1 & & 1 & & & & 4 & 193 & 199 \\
\hline Poaceae & Panicum miliaceum $\mathrm{L}$. & Common millet & $\mathrm{c}$ & $\mathrm{a}$ & 5 & & & 3 & 7 & 2 & 7 & 62 & 86 \\
\hline Poaceae & Oryza sativa $\mathrm{L}$. & Rice & $\mathrm{c}$ & $\mathrm{a}$ & 3 & 4 & & 3 & & 3 & 1 & 91 & 105 \\
\hline Poaceae & Hordeum vulgare L. & Barley & $\mathrm{c}$ & $\mathrm{a}$ & 2 & & & & 3 & & & 50 & 55 \\
\hline Poaceae & Avena sativa $\mathrm{L}$. & Oat & $\mathrm{c}$ & $\mathrm{i}$ & & & & & & 1 & 2 & 25 & 28 \\
\hline Polygonaceae & Rumex acetosa $\mathrm{L}$. & Common sorrel & w & $\mathrm{i}$ & & & & & & & 1 & & 1 \\
\hline
\end{tabular}




\begin{tabular}{|c|c|c|c|c|c|c|c|c|c|c|c|c|c|}
\hline \multirow[t]{2}{*}{ Family } & \multirow[t]{2}{*}{ Taxon } & \multirow[t]{2}{*}{ Common name } & \multirow[t]{2}{*}{ Setting } & \multirow[t]{2}{*}{ Origin } & \multicolumn{8}{|c|}{ Song type } & \multirow[t]{2}{*}{ Total } \\
\hline & & & & & $\begin{array}{l}\text { Family } \\
\text { liveli- } \\
\text { hood }\end{array}$ & $\begin{array}{l}\text { Haydu- } \\
\text { shki } \\
\text { (rebel) }\end{array}$ & Heroic & $\begin{array}{c}\text { Histo- } \\
\text { rical }\end{array}$ & Labour & Mythic & Ritual & Msc. & \\
\hline Polygonaceae & Polygonum aviculare $\mathrm{L}$. & $\begin{array}{l}\text { Common } \\
\text { knotgrass }\end{array}$ & $\mathrm{w}$ & $\mathrm{i}$ & & & & & 1 & & & & 1 \\
\hline Primulaceae & Primula sp. & Primrose & $\mathrm{w}$ & $\mathrm{i}$ & 1 & & & & & 1 & & 16 & 18 \\
\hline Ranunculaceae & Trollius europaeus L. & Globeflower & $\mathrm{w}$ & $\mathrm{i}$ & 1 & & & & & & & & 1 \\
\hline Ranunculaceae & Anemone sylvestris $\mathrm{L}$. & $\begin{array}{l}\text { Snowdrop } \\
\text { anemone }\end{array}$ & $\mathrm{w}$ & $\mathrm{i}$ & 1 & & & & & & & & 1 \\
\hline Rhamnaceae & Paliurus spina-cristi Mill. & Jerusalem thorn & $\mathrm{w}$ & $\mathrm{i}$ & & & & & & & & 1 & 1 \\
\hline Rosaceae & Rubus idaeus $\mathrm{L}$. & Raspberry & $\mathrm{c} / \mathrm{w}$ & $\mathrm{i}$ & & & & 1 & & & 1 & 37 & 39 \\
\hline Rosaceae & Rubus caesius $\mathrm{L}$. & $\begin{array}{l}\text { European } \\
\text { dewberry }\end{array}$ & $\mathrm{w}$ & $\mathrm{i}$ & 2 & & & & & & 2 & 15 & 19 \\
\hline Rosaceae & Rosa sp. & Rose & $\mathrm{c} / \mathrm{w}$ & $\mathrm{i}$ & 11 & 4 & & 1 & 4 & 3 & 7 & 135 & 165 \\
\hline Rosaceae & Rosa canina $\mathrm{L}$. & Dog rose & $\mathrm{w}$ & $\mathrm{i}$ & & & & & 1 & 1 & & 1 & 3 \\
\hline Rosaceae & $\begin{array}{l}\text { Rosa } \times \text { damascena } \mathrm{f} . \\
\text { trigintipetala }(\text { Dieck) } \\
\text { R.Keller }\end{array}$ & Damask rose & $\mathrm{c}$ & a & 1 & & & & & & & & 1 \\
\hline Rosaceae & Pyrus sp. & Pear & $\mathrm{w}$ & $\mathrm{i}$ & & & & 1 & & 1 & 1 & & 3 \\
\hline Rosaceae & Pyrus communis L. & European pear & $\mathrm{c} / \mathrm{w}$ & $\mathrm{i}$ & 4 & & & & 3 & & 1 & 53 & 61 \\
\hline Rosaceae & Prunus spinosa $L$. & Blackthorn & $\mathrm{w}$ & $\mathrm{i}$ & & & & & & 1 & 1 & 4 & 6 \\
\hline Rosaceae & $\begin{array}{l}\text { Prunus dulcis (Mill.) D. A. } \\
\text { Webb }\end{array}$ & Almond & $\mathrm{c}$ & a & & & & & 1 & & 1 & 3 & 5 \\
\hline Rosaceae & Prunus domestica L. & Plum & $\mathrm{c}$ & $\mathrm{a}$ & & & & & & 1 & 2 & & 3 \\
\hline Rosaceae & Prunus cerasus $\mathrm{L}$. & Sour cherry & $\mathrm{c}$ & a & 2 & & & & 2 & & 1 & 150 & 155 \\
\hline Rosaceae & Prunus avium (L.) L. & Sweet cherry & $\mathrm{c} / \mathrm{w}$ & $\mathrm{i}$ & 5 & 1 & & 1 & 2 & 2 & 6 & 194 & 211 \\
\hline Rosaceae & Prunus armeniaca $\mathrm{L}$. & Apricot & $\mathrm{c}$ & $\mathrm{a}$ & 1 & & & & & & & & 1 \\
\hline Rosaceae & Malus sylvestris (L.) Mill. & $\begin{array}{l}\text { European crab } \\
\text { apple }\end{array}$ & $\mathrm{w}$ & $\mathrm{i}$ & & & & & 2 & & 1 & & 3 \\
\hline Rosaceae & Malus domestica Borkh. & Apple & $\mathrm{c}$ & $\mathrm{a}$ & 13 & 3 & 2 & 1 & 2 & 5 & 9 & 260 & 295 \\
\hline Rosaceae & Fragaria sp. & Strawberry & $\mathrm{c} / \mathrm{w}$ & $\mathrm{i}$ & 1 & & & 1 & & & & 1 & 3 \\
\hline Rosaceae & Cydonia oblonga Mill. & Quince & $\mathrm{c}$ & a & & & & & 2 & 2 & 8 & 97 & 109 \\
\hline Rosaceae & Crataegus monogyna Jacq. & $\begin{array}{l}\text { Common } \\
\text { hawthorn }\end{array}$ & $\mathrm{w}$ & $\mathrm{i}$ & 1 & & & & 1 & & 1 & 8 & 11 \\
\hline Rubiaceae & Rubia tinctorum $\mathrm{L}$. & Common madder & $\mathrm{w}$ & $\mathrm{i}$ & 1 & & & & & & & & 1 \\
\hline Rubiaceae & Galium verum $\mathrm{L}$. & Lady's bedstraw & $\mathrm{w}$ & $\mathrm{i}$ & & & & & 1 & & & & 1 \\
\hline
\end{tabular}




\begin{tabular}{|c|c|c|c|c|c|c|c|c|c|c|c|c|c|}
\hline \multirow[t]{2}{*}{ Family } & \multirow[t]{2}{*}{ Taxon } & \multirow[t]{2}{*}{ Common name } & \multirow[t]{2}{*}{ Setting } & \multirow[t]{2}{*}{ Origin } & \multicolumn{8}{|c|}{ Song type } & \multirow[t]{2}{*}{ Total } \\
\hline & & & & & $\begin{array}{l}\text { Family } \\
\text { liveli- } \\
\text { hood }\end{array}$ & $\begin{array}{c}\text { Haydu- } \\
\text { shki } \\
\text { (rebel) }\end{array}$ & Heroic & $\begin{array}{c}\text { Histo- } \\
\text { rical }\end{array}$ & Labour & Mythic & Ritual & Msc. & \\
\hline Rubiaceae & Coffea arabica $\mathrm{L}$. & Arabian coffee & ip & & 1 & & & & & & & & 1 \\
\hline Rutaceae & Dictamnus albus $\mathrm{L}$. & Burning bush & $\mathrm{w}$ & $\mathrm{i}$ & 1 & & & & & & 1 & 1 & 3 \\
\hline Rutaceae & Citrus sinensis (L.) Osbeck & Orange & ip & & 1 & & & & & & 1 & 1 & 3 \\
\hline Rutaceae & Citrus limon (L.) Osbeck & Lemon & $\mathrm{c}$ & a & 1 & & & & & & & 2 & 3 \\
\hline Salicaceae & Salix sp. & Willow & w & i & 2 & & & 1 & & 2 & 2 & 71 & 78 \\
\hline Salicaceae & Salix alba $\mathrm{L}$. & White willow & $\mathrm{w}$ & $\mathrm{i}$ & & & & & 1 & & & & 1 \\
\hline Salicaceae & Populus tremula $\mathrm{L}$. & Common aspen & $\mathrm{w}$ & $\mathrm{i}$ & 1 & & & & & 1 & 4 & 43 & 49 \\
\hline Salicaceae & Populus sp. & Poplar & $\mathrm{w}$ & $\mathrm{i}$ & 5 & & & & & 1 & 2 & 42 & 50 \\
\hline Scrophulariaceae & Verbascum phlomoides $\mathrm{L}$. & Orange mullein & $\mathrm{w}$ & $\mathrm{i}$ & & & & & & & 1 & & 1 \\
\hline Solanaceae & Solanum melongena $\mathrm{L}$. & Eggplant & $\mathrm{c}$ & $\mathrm{a}$ & & & & & & & & 1 & 1 \\
\hline Solanaceae & Solanum lycopersicum $\mathrm{L}$. & Tomato & $\mathrm{c}$ & $\mathrm{n}$ & & & & & & & & 1 & 1 \\
\hline Solanaceae & Capsicum аппит $\mathrm{L}$. & Chilli/pepper & $\mathrm{c}$ & $\mathrm{n}$ & & & & & & & 1 & 8 & 9 \\
\hline Tropaeolaceae & Tropaeolum majus L. & $\begin{array}{l}\text { Garden } \\
\text { nasturtium }\end{array}$ & c & $\mathrm{i}$ & & & & & & 1 & & 6 & 7 \\
\hline Urticaceae & Urtica dioica $\mathrm{L}$. & Stinging nettle & w & $\mathrm{i}$ & 1 & & & & 1 & & & 8 & 10 \\
\hline Violaceae & Viola sp. & Violet & w & $\mathrm{i}$ & 1 & & & & 1 & 1 & 2 & 7 & 12 \\
\hline Vitaceae & $\begin{array}{l}\text { Vitis vinifera cv. } \\
\text { Karagevrek }\end{array}$ & $\begin{array}{l}\text { Grapevine cv. } \\
\text { Karagevrek }\end{array}$ & $\mathrm{c}$ & $\mathrm{i}$ & & & & & & & 2 & & 2 \\
\hline Vitaceae & $\begin{array}{l}\text { Vitis vinifera cv. Kadan } \\
\text { parmak }\end{array}$ & $\begin{array}{l}\text { Grapevine cv. } \\
\text { Kadan parmak }\end{array}$ & c & $\mathrm{i}$ & & & & & & & 2 & & 2 \\
\hline Vitaceae & Vitis vinifera $\mathrm{L}$. & Grapevine & $\mathrm{c} / \mathrm{w}$ & $\mathrm{i}$ & 4 & & 1 & & 3 & 10 & 13 & 248 & 279 \\
\hline NOID & NOID & Breshnel & $\mathrm{w}$ & & & & & & & & 1 & & 1 \\
\hline NOID & NOID & Gergevo tsvete & w & & & & & & & & 1 & & 1 \\
\hline NOID & NOID & Gorotsvet & $\mathrm{w}$ & & & & & & 1 & 1 & & 1 & 3 \\
\hline NOID & NOID & Keferichno darvo & & & & & 1 & & & & & & 1 \\
\hline NOID & NOID & Kifire & & & 1 & & & & & & & & 1 \\
\hline NOID & NOID & Kuma & w & & & & & & & 1 & & & 1 \\
\hline NOID & NOID & $\begin{array}{l}\text { Ovtcharska } \\
\text { perenuga }\end{array}$ & w & & & & & & & & & 1 & 1 \\
\hline NOID & NOID & Gorchiv lapad & $\mathrm{w}$ & & & & & & & 1 & & & 1 \\
\hline
\end{tabular}




\begin{tabular}{|c|c|c|c|c|c|c|c|c|c|c|c|c|c|}
\hline \multirow[t]{2}{*}{ Family } & \multirow[t]{2}{*}{ Taxon } & \multirow[t]{2}{*}{ Common name } & \multirow[t]{2}{*}{ Setting } & \multirow[t]{2}{*}{ Origin } & \multicolumn{8}{|c|}{ Song type } & \multirow[t]{2}{*}{ Total } \\
\hline & & & & & $\begin{array}{c}\text { Family } \\
\text { liveli- } \\
\text { hood }\end{array}$ & $\begin{array}{c}\text { Haydu- } \\
\text { shki } \\
\text { (rebel) }\end{array}$ & Heroic & $\begin{array}{c}\text { Histo- } \\
\text { rical }\end{array}$ & Labour & Mythic & Ritual & Msc. & \\
\hline NOID & NOID & Ruzha & $\mathrm{c} / \mathrm{w}$ & & 3 & 1 & & & 1 & 1 & & 3 & 9 \\
\hline NOID & NOID & Ruzha zhulta & $\mathrm{c} / \mathrm{w}$ & & & & & & & & 1 & & 1 \\
\hline NOID & NOID & Sifa & $\mathrm{c}$ & & 1 & & & & & & & 1 & 2 \\
\hline NOID & NOID & Smilna kitka & $\mathrm{w}$ & & & & 1 & & & & & & 1 \\
\hline NOID & NOID & Sminchec & $\mathrm{w}$ & & 1 & & & & & & & & 1 \\
\hline NOID & NOID & Sminova kitka & $\mathrm{w}$ & & & & & & & & 1 & & 1 \\
\hline \multirow[t]{2}{*}{ NOID } & NOID & Vidrovo durvo & & & 1 & & & & & & & & 1 \\
\hline & & & & $\begin{array}{c}\text { Grand } \\
\text { total }\end{array}$ & 167 & 40 & 16 & 39 & 129 & 144 & 287 & 3,255 & 4,077 \\
\hline
\end{tabular}

Setting: in cultivation/crop (c); wild (w); imported food product (ip)

Origin: indigenous species (i); archaeophyte (a); neophyte (n) 